\title{
Childhood intussusception: 17-year experience at a tertiary referral centre in Hong Kong
}

\author{
Carol WY Wong, Ivy HY Chan, Patrick HY Chung, Lawrence CL Lan, Wendy WM Lam, \\ Kenneth KY Wong *, Paul KH Tam
}

\section{A B S T R A C T}

Objectives: To review all paediatric patients with intussusception over the last 17 years.

Design: Retrospective case series.

Setting: A tertiary centre in Hong Kong.

Patients: Children who presented with intussusception from January 1997 to December 2014 were reviewed.

Main outcome measures: The duration of symptoms, successful treatment modalities, complication rate, and length of hospital stay were studied.

Results: A total of 173 children (108 male, 65 female) presented to our hospital with intussusception during the study period. Their median age at presentation was 12.5 months (range, 2 months to 16 years) and the mean duration of symptoms was 2.3 (standard deviation, 1.8) days. Vomiting was the most common symptom (76.3\%) followed by abdominal pain $(46.2 \%)$, per rectal bleeding or red currant jelly stool (40.5\%), and a palpable abdominal mass (39.3\%). Overall, 160 patients proceeded to pneumatic or hydrostatic reduction, among whom $127(79.4 \%)$ were successful. Three (1.9\%) patients

This article was published on 11 Sep 2015 at www.hkmj.org. had bowel perforation during the procedure. Early recurrence of intussusception occurred in four (3.1\%) patients with non-operative reduction. No recurrence was reported in the operative group. The presence of a palpable abdominal mass was a risk factor for operative treatment (relative risk $=2.0$; $95 \%$ confidence interval, 1.8-2.2). Analysis of our results suggested that duration of symptoms did not affect the success rate of non-operative reduction.

Conclusions: Non-operative reduction has a high success rate and low complication rate, but the presence of a palpable abdominal mass is a risk factor for failure. Operative intervention should not be delayed in those patients who encounter difficult or doubtful non-operative reduction.

\section{Hong Kong Med J 2015;21:518-23 \\ DOI: 10.12809/hkmj144456}

${ }^{1}$ CWY Wong, MB, BS, MRCSEd

${ }^{1}$ IHY Chan, MB, BS, FHKAM (Surgery)

${ }^{1}$ PHY Chung, MB, BS, FHKAM (Surgery)

${ }^{1}$ LCL Lan, MB, BS, FHKAM (Surgery)

${ }^{2}$ WWM Lam, MB, BS, FHKAM (Radiology)

${ }^{1}$ KKY Wong *, PhD, FHKAM (Surgery)

${ }^{1}$ PKH Tam, ChM, FHKAM (Surgery)

1 Department of Surgery, The University of Hong Kong, Queen Mary Hospital, Pokfulam, Hong Kong

Department of Radiology, Queen Mary Hospital, Pokfulam, Hong Kong

* Corresponding author: kkywong@hku.hk

New knowledge added by this study

- Non-operative reduction of intussusception has a high success rate and low complication rate, even in delayed presentation of over 72 hours.

- The presence of a palpable abdominal mass is a risk factor for failure of non-operative reduction.

Implications for clinical practice or policy

- Non-operative reduction is recommended as the first-line treatment for children with intussusception.

- Operative intervention should not be delayed in those patients who encounter difficult or doubtful nonoperative reduction.

\section{Introduction}

Intussusception is the most common cause of intestinal obstruction in infants and young children between the age of 3 months and 3 years, and the peak age of presentation is 4 to 8 months. ${ }^{1}$ The invagination of proximal bowel into more distal bowel results in venous congestion and bowel wall oedema. If this condition is not promptly diagnosed and treated, arterial obstruction and bowel necrosis and perforation may occur. ${ }^{2}$ Approximately $90 \%$ of intussusceptions in the paediatric age-group are ileocolic and idiopathic, ${ }^{3}$ presumably caused by lymphoid hyperplasia that has been suggested as the 'lead point' in its pathogenesis. ${ }^{4}$ Viral infection may also play a role..$^{5-8}$

The reported incidence of a pathological lead point in paediatric intussusception is approximately $6 \%,{ }^{9}$ the most common of which 
is Meckel's diverticulum. ${ }^{10}$ Systemic conditions such as Henoch-Schönlein purpura, Peutz-Jeghers syndrome, and familial polyposis can also increase the risk of intussusception. Abdominal trauma and postoperative abdomen have also been reported to pose a higher risk for intussusception. ${ }^{11-14}$

The presenting symptoms of intussusception are often non-specific and may mimic viral gastroenteritis, presenting as vomiting and diarrhoea. The classic triad of red currant jelly stool, abdominal pain, and abdominal mass is not often encountered, and the diagnosis may easily be delayed or missed. ${ }^{15}$ Plain abdominal films are neither sensitive nor specific for intussusception and may be completely normal. ${ }^{16}$ The most consistent finding is a paucity of gas in the right iliac fossa. Other possible features include soft tissue mass, target sign, or meniscus sign. ${ }^{17}$ The first-line investigation for diagnosis of intussusception in children is abdominal ultrasound, given its high sensitivity (98\%-100\%) and specificity (88\%-100\%). ${ }^{18}$

Non-operative reduction methods for intussusception include barium enema, and hydrostatic or pneumatic reduction. ${ }^{19}$ Pneumatic reduction is currently the preferred standard treatment, given the greater ease of performing the examination, the lesser morbidity with complications, and the slightly higher success rate of $84 \%$ to $100 \%{ }^{20-22}$

Operative reduction is required when nonoperative reduction is either contra-indicated (eg peritonitis, perforation, profound shock) or unsuccessful. Open surgery has been the conventional approach although laparoscopic reduction is also feasible and successful in uncomplicated cases..$^{23,24}$

In this study, we aimed to review our hospital's experience in the management of paediatric intussusception over the last 17 years, with a focus on assessing the efficacy of non-operative reduction and identifying the risk factors that may lower its success rate.

\section{Methods}

We conducted a retrospective study of children who presented with intussusception from January 1997 to December 2014 in our hospital. We started with the year 1997 as some of earlier records were incomplete. Patient demographics, clinical presentation, duration of symptoms, treatment modalities, complication rate, and length of hospital stay were studied. The method of non-operative reduction in our institution was ultrasound-guided hydrostatic reduction before 2005 and pneumatic reduction with fluoroscopy after 2005, as the latter was easier and faster to perform. The procedure was performed by paediatric radiologists, with a paediatric surgeon available if necessary. In pneumatic reduction, air is insufflated via a Foley catheter (with size of $18-\mathrm{Fr}$

\section{小兒腸套疊：香港一所提供第三層醫療服務的 醫院的十七年經驗}

黃詠欣、陳巧兒、鍾浩宇、藍傳亮、林慧文、黃格元、譚廣亨

目的：研究過往 17 年所有小兒腸套疊患者。

設計：回顧病例系列。

安排：香港一所提供第三層醫療服務的醫院。

患者：回顧1997年1月至2014年12月期間所有小兒腸套疊患者。

主要結果測量：症狀持續時間、成功治療的模式、併發率和住院時 間。

結果：研究期間共有 173 名兒童 (108男, 65女) 在本院確診為腸 套疊。患者病發時年齡中位數為 12.5 個月（介乎 2 個月至 16 歲） 症狀的持續時間平均為 2.3 天（標準差 1.8 天）。嘔吐是最常見的症 狀 $(76.3 \%)$, 其次為腹痛（ $46.2 \%)$, 直腸出血或啫啀狀的血便 （40.5\%），以及腹部一個可捫及腫塊（39.3\%）。進行空氣或水壓灌 腸復位的 160 例中, 有 127 例 $(79.4 \%$ ) 成功治療此病, 3 例（1.9\%） 在治療過程中出現腸道穿孔。接受非手術復位的病例中, 有 4 例 （3.1\%）出現早期腸套疊復發。手術治療的病例中則沒有復發病例。 腹部可捫及腫塊是需要手術治療的一項風險因素（相對風險度 $=2.0$; 95\%置信區間：1.8-2.2）。本研究的結果顯示症狀持續時間並無影響 非手術療法的成功率。

結論：非手術復位的治療成功率高、併發率低, 但腹部可捫及腫塊是 非手術治療失敗的一項風險因素。如果灌腸復位失敗或者在非手術治 療過程中遇到困難時, 便須進行緊急手術。

to 22-Fr, depending on patient's size, with balloon inflated with $10 \mathrm{~mL}$ water) placed inside the patient's rectum under pressure monitoring at $120 \mathrm{~mm} \mathrm{Hg}$. Our radiologists would perform a maximum of three attempts. The patient might be given intravenous midazolam at a dose of 0.1 to $0.2 \mathrm{mg} / \mathrm{kg}$ if necessary. Successful reduction was demonstrated by free flow of air into the terminal ileum and disappearance of the caecal soft tissue mass.

For laparoscopic reduction, a 5-mm subumbilical port was used for camera access. Another two working ports (one in the upper and one in the lower abdomen) were inserted. Reduction of intussusception was performed with laparoscopic graspers. In open reduction, manual reduction was achieved by milking the intussusceptum out of the intussuscipient. Bowel resection was performed when bowel necrosis was found intra-operatively.

Data analysis was carried out using the Statistical Package for the Social Sciences (Windows version 21.0; SPSS Inc, Chicago [IL], US). Mean values were expressed with standard deviation. Continuous variables were compared with Mann-Whitney $U$ test and categorical values with Chi squared test. Results were considered statistically significant when $\mathrm{P} \leq 0.05$. Comparison of success, recurrence, and complication rates between hydrostatic and pneumatic reduction groups was performed. The length of hospital stay was also compared. 


\section{Results}

A total of 173 children (108 male, 65 female) presented to our hospital with intussusception during the study period. Of them, 83 (48\%) were admitted directly to our paediatric surgical ward, 50 (29\%) were referred from the paediatric medical ward in our hospital, and the remaining 40 (23\%) were referred from other public and private hospitals. The median age at presentation was 12.5 months (range, 2 months to 16 years) and the mean ( \pm standard deviation) duration of presenting symptoms was 2.3 \pm 1.8 days. The common presenting symptoms and their percentage of occurrence are shown in Table 1. The most common symptom reported was vomiting and occurred in 132 (76.3\%) patients.

All patients except one were diagnosed by ultrasonography. One patient underwent computed tomographic scan for diagnosis due to an atypical presentation of intussusception. All patients underwent either non-operative or operative treatment within 24 hours of admission. Pneumatic or hydrostatic reduction (Fig a) was performed in 160 patients, among which 127 (79.4\%) were successful and three (1.9\%) were complicated by bowel perforation. A total of 46 patients in our study required operative reduction, but two of the intussusceptions were found to be reduced upon laparotomy. These radiological misdiagnoses could be due to mistaken identity of the oedematous ileocaecal valve for intussusceptum. The indications for operative treatment are summarised in Table 1. Early recurrence of intussusception ( $<72$ hours post-reduction) occurred in four (3.1\%) of the 127 patients who had initial successful non-operative reduction. No recurrence was reported in patients treated surgically. Laparoscopic reduction was attempted in 13 patients, among whom five (38.5\%) were successful. Conversion to open reduction was required in five patients because of the need for bowel resection and in a further three due to difficult reduction. Among the 46 patients who required operative reduction, $23(50 \%)$ required bowel resection. A pathological lead point was noted intraoperatively in seven (15.2\%) patients and four had a perforated bowel (three of which were complications of non-operative reduction). The remaining $12 \mathrm{had}$ non-viable gangrenous bowel that was subsequently confirmed by histology. The operations were complicated with one burst abdomen and one anastomotic leak. The age distribution in our cohort of patients and the number of patients with pathological lead point are shown in Table 2.

We next analysed the possible risk factors for unsuccessful non-operative reduction in the 160 patients (Table 3). The only statistically significant factor was the presence of an abdominal mass (relative risk $=2.0 ; 95 \%$ confidence interval, 1.82.2). The distribution of the duration of symptoms is presented in Table 4. Nonetheless, the duration of symptoms and the extent of the intussusception did not appear to affect the chance of a successful non-operative reduction (Table 5). There were 129 patients with intussusception at the hepatic flexure or a more proximal site, 93 (72.1\%) of whom had successful non-operative reduction; 44 presented with intussusception at the transverse colon or a more distal site, of whom 34 (77.3\%) underwent successful non-operative reduction. There was no significant difference in the success rate of non-operative reduction between the two groups $(\mathrm{P}=0.56)$. Approximately $50 \%$ of patients were admitted directly to our ward from the beginning. There was no difference in the success rate of nonoperative reduction between this group of patients and those who were referred from other wards or hospitals $(77.1 \%$ vs $77.3 \%, \mathrm{P}=1.00)$.

TABLE I. Clinical presentation and indications for operative reduction

\begin{tabular}{|cc}
\hline Presenting symptom or sign & $\begin{array}{c}\text { No. (\%) of } \\
\text { patients }\end{array}$ \\
\hline Vomiting & $132(76.3)$ \\
\hline Abdominal pain & $80(46.2)$ \\
\hline Per rectal bleeding/red currant jelly stool & $70(40.5)$ \\
\hline Abdominal mass & $68(39.3)$ \\
\hline Irritability & $44(25.4)$ \\
\hline Constipation & $17(9.8)$ \\
\hline Indication for operative reduction & \\
\hline Failed non-operative reduction & $29(16.8)$ \\
\hline Haemodynamic instability & $5(2.9)$ \\
\hline $\begin{array}{l}\text { Bowel perforation during non-operative } \\
\text { reduction }\end{array}$ & $3(1.7)$ \\
\hline Known pathological lead point & $2(1.2)$ \\
\hline Multiple recurrent intussusception & $1(0.6)$ \\
\hline Others & $6(3.5)$ \\
\hline
\end{tabular}

* Physical examination performed by paediatric surgical trainee or more senior staff

TABLE 2. Distribution of patient age and the number of patients with pathological lead point in each category

\begin{tabular}{lcc}
\hline Age (years) & $\begin{array}{c}\text { No. (\%) of } \\
\text { patients }\end{array}$ & $\begin{array}{c}\text { No. of patients with } \\
\text { pathological lead point }\end{array}$ \\
\hline$<0.5$ & $39(22.5)$ & 1 \\
\hline 0.5 to $<1.5$ & $64(37.0)$ & 1 \\
\hline 1.5 to $<2.5$ & $28(16.2)$ & 0 \\
2.5 to $<3.5$ & $16(9.2)$ & 0 \\
\hline 3.5 to $<4.5$ & $14(8.1)$ & 2 \\
$\geq 4.5$ & $12(6.9)$ & 3 \\
\hline Total & $\mathbf{1 7 3 ( 1 0 0 \% )}$ & $\mathbf{7}$ \\
\hline
\end{tabular}


(a)

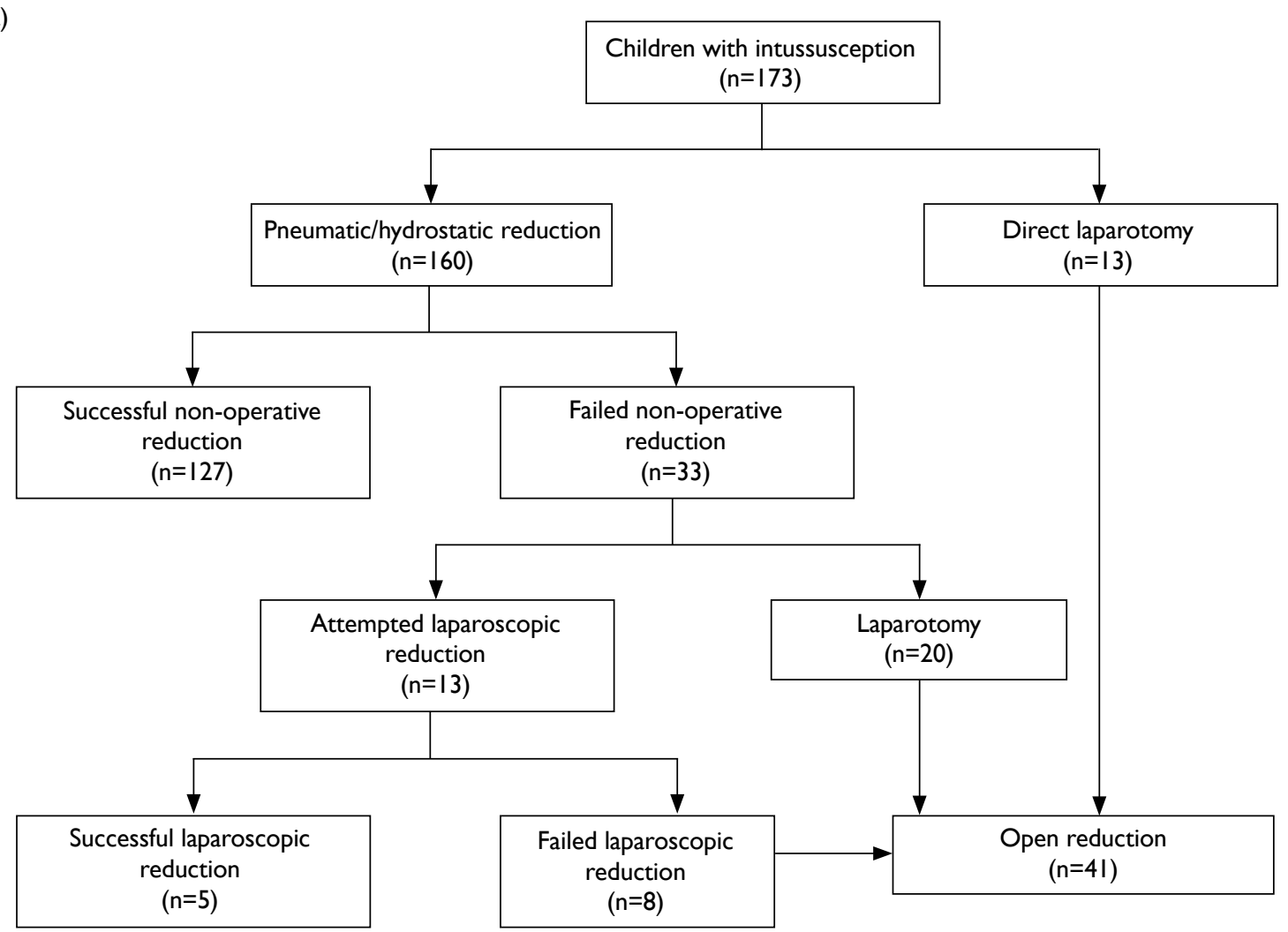

(b)

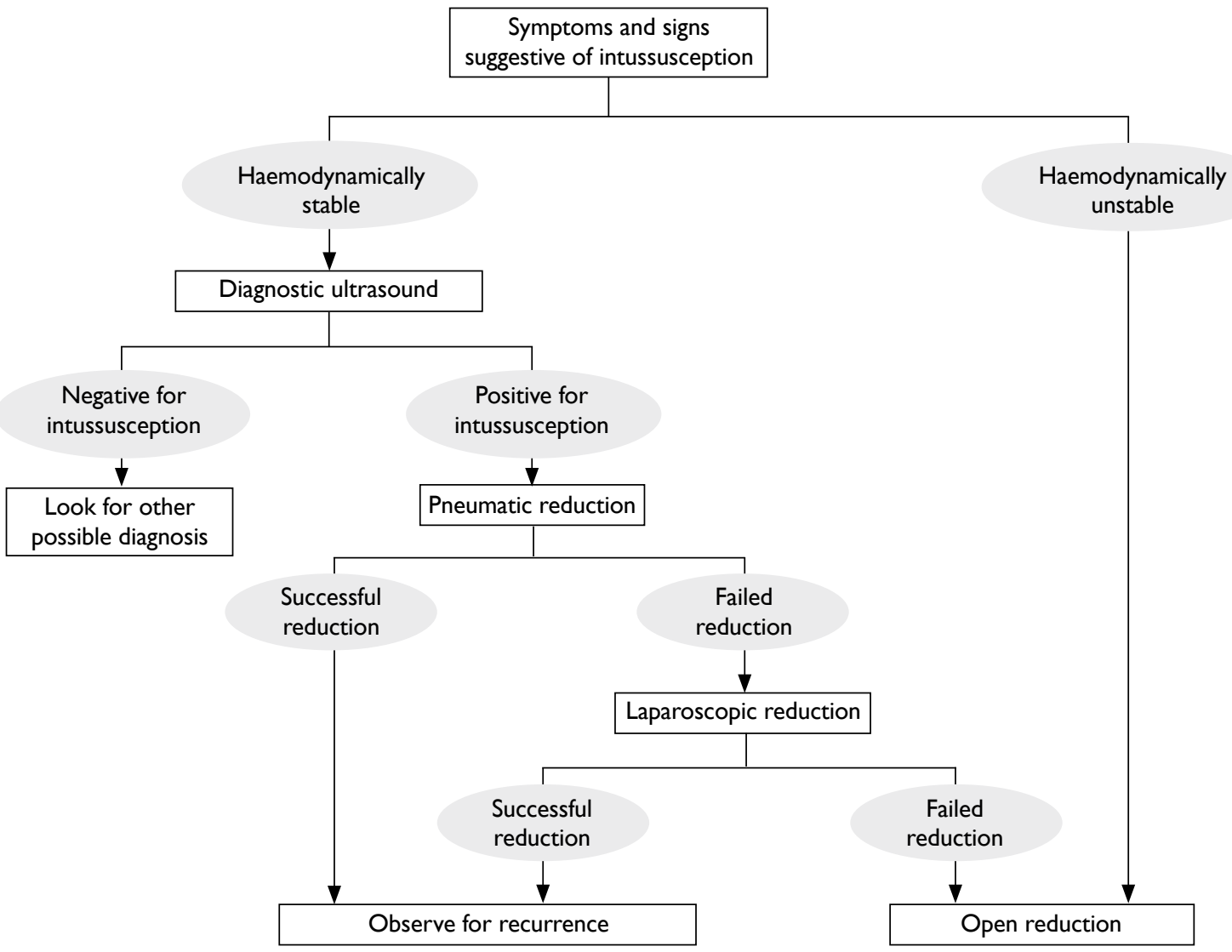

FIG. (a) Flowchart in the management of the 173 children with intussusception. (b) Recommended diagnostic and treatment algorithm in intussusception 
The overall success rate of non-operative reduction was $79.4 \%$. We also compared the success rate for the two non-operative treatment modalities. There was no statistically significant difference between the success rate of hydrostatic reduction $(81.5 \%)$ versus pneumatic reduction $(77.2 \%)$ in our study $(\mathrm{P}=0.56)$.

There was a statistically significant difference in the median length of post-reduction hospital stay for patients who were successfully treated non-operatively (3 days; range, 1-12 days) versus operatively (7.5 days; range, $3-73$ days; $\mathrm{P}=0.01$ ).

\section{Discussion}

Intussusception is a true paediatric surgical emergency and is second only to appendicitis as the most common cause of an acute abdominal emergency in children. ${ }^{25}$ The complete classic triad of intermittent abdominal pain, red currant jelly stool, and a palpable abdominal mass is not a common presentation. ${ }^{26}$ Only five $(2.9 \%)$ of our patients were documented to have all three symptoms present at the time of hospital admission. In accordance with previous studies, vomiting was the most common presenting symptom. ${ }^{4,27}$ Per rectal bleeding or red currant jelly stool signify bowel ischaemia and mucosal sloughing but is a rather late sign and was present in only $40.5 \%$ of our patients. Nonetheless, all except one patient had at least one of the symptoms of abdominal pain, abdominal mass, red currant jelly stool, vomiting, or irritability. These symptoms should be actively sought in any patient in whom intussusception is suspected.

The most reliable abdominal sign, if present, is a palpable mass in the right upper quadrant of the abdomen. It was present in $39.3 \%$ of our patients, and was a risk factor for the need of operative treatment. We postulate that a palpable mass may signify relatively longer duration of intussusception that causes complete intestinal obstruction, thus rendering non-operative reduction less successful as it becomes more difficult for the reduction medium to pass through. Many children with intussusception present with non-specific signs and symptoms, thus the diagnosis may easily be delayed or missed. ${ }^{15}$ Therefore, as clinicians we must maintain a high index of suspicion in order to identify this emergency in a timely manner. Early referral of suspected cases to a tertiary treatment centre can significantly reduce morbidity in the child.

With positive sonographic findings of intussusception, an enema is reserved for therapeutic purposes, although it may be necessary for diagnosis when ultrasonography findings are questionable. Computed tomography is seldom needed for diagnosis of paediatric intussusception, except in cases where an associated underlying pathological lead point is suspected. Our recommended diagnostic and treatment algorithm is summarised in Figure b. Pneumatic reduction is currently our preferred standard treatment of intussusception, given the greater ease of performing the examination, lesser morbidity with complication, and the high success rate. ${ }^{20-22}$ Major advantages of air enema reduction include a relatively low radiation dose and improved safety with constant pressure monitoring. ${ }^{28,29}$ The perforation rate is reported to be less than $3 \% .^{30}$ In a randomised trial performed by Hadidi and El Shal, ${ }^{22}$ pneumatic reduction was concluded to be the modality with fewest complications and highest success rate, when compared with barium enema and hydrostatic reduction. In our study, there was no statistically significant difference in the success rate between hydrostatic reduction and pneumatic reduction $(81.5 \%$ vs $77.2 \%, \mathrm{P}=0.56)$. We believe that this is attributable to the fact that both hydrostatic and pneumatic reductions are based on similar principles.

Laparoscopic reduction has been demonstrated to be feasible and successful in uncomplicated intussusception. ${ }^{23,24}$ In our series, five (62.5\%) of the eight conversions from laparoscopic to open reduction were due to the need for bowel resection.

Non-operative reduction has a high overall success rate and low complication and recurrence rates. A high success rate was observed even in the group of patients with delayed presentation of over 72 hours. It also leads to a shorter hospital stay and is therefore recommended as the first-line treatment of this condition.

The presence of a palpable abdominal mass is a risk factor for failure of non-operative reduction. Operative intervention should not be delayed in these patients who encounter difficult or doubtful non-operative reduction. For patients in whom nonoperative reduction fails, laparoscopic reduction appears to be a feasible option. From our experience, a significant proportion of this group of patients

TABLE 3. Possible risk factors for unsuccessful non-operative reduction

\begin{tabular}{lccc}
\hline Risk factor & $\begin{array}{c}\text { Successful non-operative } \\
\text { reduction }(\mathbf{n = 1 2 7})\end{array}$ & $\begin{array}{c}\text { Operative reduction } \\
\mathbf{( n = 4 6 )}\end{array}$ & P value \\
\hline Presence of an abdominal mass & $42(33.1 \%)$ & $31(67.4 \%)$ & 0.001 \\
Presence of per rectal bleeding or red currant jelly stool & $51(40.2 \%)$ & $18(39.1 \%)$ & 1.000 \\
Mean duration of presenting symptoms (days) & 1.08 & 1.27 & 0.467 \\
Mean age (years) & 1.80 & 1.54 & 0.280 \\
\hline
\end{tabular}


TABLE 4. Distribution of patients in relation to the duration of symptoms

\begin{tabular}{lcc}
\hline $\begin{array}{l}\text { Duration of } \\
\text { symptoms (hours) }\end{array}$ & $\begin{array}{c}\text { No. (\%) of } \\
\text { patients }\end{array}$ & $\begin{array}{c}\text { Success rate of non- } \\
\text { operative reduction }\end{array}$ \\
\hline$<24$ & $68(39.3)$ & $75.8 \%$ \\
24 to $<48$ & $81(46.8)$ & $83.1 \%$ \\
48 to $<72$ & $9(5.2)$ & $85.7 \%$ \\
$\geq 72$ & $15(8.7)$ & $70 \%$ \\
\hline
\end{tabular}

TABLE 5. Success rates of non-operative reduction in relation to the duration of symptoms

\begin{tabular}{|c|c|c|}
\hline $\begin{array}{l}\text { Duration of } \\
\text { symptoms (hours) }\end{array}$ & $\begin{array}{l}\% \text { Of successful non- } \\
\text { operative reduction }\end{array}$ & $P$ value \\
\hline 24 & & 0.67 \\
\hline$<24$ & 78.3 & \\
\hline$\geq 24$ & 82.2 & \\
\hline 48 & & 0.75 \\
\hline$<48$ & 79.7 & \\
\hline$\geq 48$ & 76.5 & \\
\hline 72 & & 0.43 \\
\hline$<72$ & 80.0 & \\
\hline$\geq 72$ & 70.0 & \\
\hline
\end{tabular}

require bowel resection. If the viability of the bowel is doubtful during laparoscopy, early conversion to open surgery should be performed in order to avoid delay in treatment.

\section{Conclusions}

Non-operative reduction has a high success rate and low complication rate, but the presence of a palpable abdominal mass is a risk factor for failure. Operative intervention should not be delayed in these patients who encounter difficult or doubtful non-operative reduction.

\section{References}

1. Bines J, Ivanoff B. Acute intussusception in infants and children: incidence, clinical presentation and management: a global perspective. Report 02.19. Geneva: World Health Organization; 2002.

2. Stringer MD, Pablot SM, Brereton RJ. Paediatric intussusception. Br J Surg 1992;79:867-76.

3. Bajaj L, Roback MG. Postreduction management of intussusception in a children's hospital emergency department. Pediatrics 2003;112:1302-7.

4. DiFiore JW. Intussusception. Semin Pediatr Surg 1999;8:214-20.

5. Mayell MJ. Intussusception in infancy and childhood in Southern Africa. A review of 223 cases. Arch Dis Child 1972;47:20-5.

6. Mangete ED, Allison AB. Intussusception in infancy and childhood: an analysis of 69 cases. West Afr J Med 1994;13:87-90.

7. Asano Y, Yoshikawa T, Suga S, Hata T, Yamazaki T, Yazaki T. Simultaneous occurrence of human herpesvirus 6 infection and intussusception in three infants. Pediatr Infect Dis J 1991;10:335-7.

8. O’Ryan M, Lucero Y, Peña A, Valenzuela MT. Two year review of intestinal intussusception in six large public hospitals of Santiago, Chile. Pediatr Infect Dis J 2003;22:717-21.

9. Blakelock RT, Beasley SW. The clinical implications of nonidiopathic intussusception. Pediatr Surg Int 1998;14:163-7.

10. Navarro O, Dugougeat F, Kornecki A, Shuckett B, Alton DJ, Daneman A. The impact of imaging in the management of intussusception owing to pathologic lead points in children. A review of 43 cases. Pediatr Radiol 2000;30:594-603.

11. Komadina R, Smrkolj V. Intussusception after blunt abdominal trauma. J Trauma 1998;45:615-6.

12. Stockinger ZT, McSwain N Jr. Intussusception caused by abdominal trauma: case report and review of 91 cases reported in the literature. J Trauma 2005;58:187-8.

13. Türkyilmaz Z, Sönmez K, Demiroğullari B, et al. Postoperative intussusception in children. Acta Chir Belg 2005;105:187-9.

14. Emil S, Shaw X, Laberge JM. Post-operative colocolic intussusception. Pediatr Surg Int 2003;19:220-2.

15. Reijnen JA, Festen C, Joosten HJ, van Wieringen PM. Atypical characteristics of a group of children with intussusception. Acta Paediatr Scand 1990;79:675-9.

16. Hernandez JA, Swischuk LE, Angel CA. Validity of plain films in intussusception. Emerg Radiol 2004;10:323-6.

17. Ratcliffe JF, Fong S, Cheong I, O'Connell P. The plain abdominal film in intussusception: the accuracy and incidence of radiographic signs. Pediatr Radiol 1992;22:110-1.

18. Bhisitkul DM, Listernick R, Shkolnik A, et al. Clinical application of ultrasonography in the diagnosis of intussusception. J Pediatr 1992;121:182-6.

19. Peh WC, Khong PL, Lam C, et al. Reduction of intussusception in children using sonographic guidance. AJR Am J Roentgenol 1999;173:985-8.

20. Lui KW, Wong HF, Cheung YC, et al. Air enema for diagnosis and reduction of intussusception in children: clinical experience and fluoroscopy time correlation. J Pediatr Surg 2001;36:479-81.

21. Rubí I, Vera R, Rubí SC, et al. Air reduction of intussusception. Eur J Pediatr Surg 2002;12:387-90.

22. Hadidi AT, El Shal N. Childhood intussusception: a comparative study of nonsurgical management. J Pediatr Surg 1999;34:304-7.

23. Schier F. Experience with laparoscopy in the treatment of intussusception. J Pediatr Surg 1997;32:1713-4.

24. Poddoubnyi IV, Dronov AF, Blinnikov OI, Smirnov AN, Darenkov IA, Dedov KA. Laparoscopy in the treatment of intussusception in children. J Pediatr Surg 1998;33:1194-7.

25. Waseem M, Rosenberg HK. Intussusception. Pediatr Emerg Care 2008;24:793-800.

26. Bruce J, Huh YS, Cooney DR, Karp MP, Allen JE, Jewett TC Jr. Intussusception: evolution of current management. J Pediatr Gastroenterol Nutr 1987;6:663-74.

27. Losek JD. Intussusception: don't miss the diagnosis! Pediatr Emerg Care 1993;9:46-51.

28. Stringer DA, Ein SH. Pneumatic reduction: advantages, risks and indications. Pediatr Radiol 1990;20:475-7.

29. Meyer JS, Dangman BC, Buonomo C, Berlin JA. Air and liquid contrast agents in the management of intussusception: a controlled, randomized trial. Radiology 1993;188:507-11.

30. Daneman A, Alton DJ, Ein S, Wesson D, Superina R, Thorner P. Perforation during attempted intussusception reduction in children-a comparison of perforation with barium and air. Pediatr Radiol 1995;25:81-8. 